\title{
Determinants of the spatial diffusion of Bollywood cinema
}

\begin{abstract}
The aim of the paper is to indicate which determinants had the major impact on the spatial diffusion of the Bollywood cinema in two aspects: the first appearance of this cinema in different countries and the number of films distributed there. The distance between the country and Mumbai and the size of the diaspora were taken as key determinants. The concept of Hägerstrand was adopted as the spatial diffusion model. The procedure involved gathering data for 5,832 Hindi movies produced in Mumbai distributed in cinemas in 76 countries from 1970 to 2010. The hypotheses were verified and it was proved that the spatial diffusion of the popular hindi cinema was influenced by a number of social, cultural and political determinants, of which the size of the Indian diaspora was the most important. The paper can be a reference to the discussion about diaspora identity and the intersection of cultures.
\end{abstract}

\section{Keywords}

Spatial diffusion • spatial diffusion determinants • Bollywood • Bollywood cinema; popular hindi cinema

(C) University of Warsaw - Faculty of Geography and Regional Studies

\author{
Małgorzata Parda \\ Faculty of Geography and Regional Studies, \\ University of Warsaw, Warsaw, Poland \\ e-mail:mparda.geo@gmail.com \\ Received: 5 June 2018 \\ Accepted: 16 September 2018
}

Introduction

Bollywood is one of many cinematographic centres in India. It has its seat in Mumbai, where most of its movies are shot. The centre produces approximately 200 movies per year, with nearly 2.5 million people working on them, which makes Bollywood the biggest movie centre in the world (Stachówna \& Piekarski 2009). In this publication the notion of "Bollywood cinema" is taken to mean all the movies produced at least in part in Mumbai, and with Hindi as the prevailing language. At the turn of the $21^{\text {st }}$ century, there were many reports regarding Bollywood cinema and its diffusion to selected countries, whose authors were: A. G. Roy (2012), A. G. Roy and C. B. Huat (2012), R. Kaur and A. J. Sinha (2005) and R. B. Mehta and R. Pandharipande (2010). These works provide detailed analyses of selected productions and the history of Bollywood. However, no attempts have been made to determine the conditions in which Bollywood cinema was popularised all around the world. This paper is a summary of the key determinants that contributed to the diffusion of Bollywood cinema in all the countries in which these movies were distributed. In order to achieve the goals of the paper, an analysis was made of the distribution of all Bollywood films within a specific time frame - from 1970 to 2010. The analysis was carried out in an intervallic manner, so four full decades were used. The year 1970 was chosen as the beginning, because before that date the cinema distribution of Bollywood films in the world was sporadic and limited to only a few titles. It is worth specifying that the subject of the work is only Bollywood films with official cinematic distribution. Other media (DVD, VOD, YouTube and others) that are also popular, but equally difficult to measure and subject to reliable analysis, have not been included. For similar reasons, the focus was only on films produced in Mumbai and in Hindi or with Hindi as the dominant language. They constituted a large group of over 5,800 films.

As an element of Hägerstrand's theory, the "neighbourhood effect" could play a key role in the diffusion of popular Hindi cinema, so the assumptions of his concept were used in the work.

The commonly accepted definition by T. Hägerstrand (1967) says that "[t]he diffusion of innovations - the origin and dissemination of cultural novelties - is an area of study which concerns all sciences dealing with human activity, including, not least of all, cultural and economic geography," (1967 p. 1). Thus, diffusion of innovation theory tries to explain why and how this process of disseminating a new technological idea takes place. T. Hägerstrand (1967) isolated a neighbourhood effect and a wave model of spatial diffusion, among others. The first concerns the high probability of a community accepting an innovation when a neighbouring community has already accepted it. The wave theory compares the diffusion of innovation to circular ripples on water that are formed when a stone is thrown into it. They spread concentrically, starting with the source of information until the moment they reach the outer radius. For the innovation to diffuse according to the model it is necessary that it proceed in a perfectly homogeneous environment and not be disturbed.

The aim of information regarding a diverse group of countries (Pakistan, Nepal, Bangladesh, South Africa, Australia, Soviet Union [Russia since 1991], and Senegal) is to highlight the importance of other circumstances in this process that contributed to changing the course of the spatial diffusion. This research has also been prompted by the spectacular phenomenon of 
Bollywood cinema in countries distant both spatially and culturally from India that was observed in the $1^{\text {st }}$ decade of the $21^{\text {st }}$ century. According to the directory of movies made in Bollywood in the last hundred years of this cinematographic centre's operation, 5,832 movies were made there within the years 1970-2010. All of them have been analysed here.

The concept of spatial diffusion, as well as the nature of an analysed innovation, allowed the following hypotheses to be proposed:

1. The distance of reception countries from Mumbai does not influence the time of distribution nor the number of distributed Bollywood movies.

2. In countries with a strong Indian diaspora the distribution of Bollywood movies started earlier and more Bollywood movies were distributed there than in other countries.

3. The importance of the distance and size of a diaspora with the course of Bollywood cinema diffusion is subordinate to other political and cultural circumstances.

\section{Test procedure}

To achieve the research objectives the following test procedure was carried out:

1. All the Bollywood movies distributed in cinemas all over the world in 1970-2010 were gathered. Movies with a prevailing language other than Hindi were rejected. Thus, the final number of movies was 5,832 .

2. On the basis of the information gathered from IMDb (2017), data regarding world premieres of each of the movies was collected. The year of the first premiere and all countries of distribution were key.

3. Based on the gathered information, 76 countries were selected in which the spatial diffusion of Bollywood cinema was present. For each, the time of the $1^{\text {st }}$ premiere of Bollywood cinema in the referred period, and the number of distributed movies, were specified.

4. Information regarding the distance from Mumbai to the reception countries (measuring to the largest urban centre) and the size of the Indian diaspora in the reception countries was collected. The data regarding distances was acquired from the DistanceFromTo (2017) website, and data regarding the diaspora from the reports of the High Level Committee On Indian Diaspora $(2001,2016)$ and the International Migration Report 2015 published by the Department of Economic and Social Affairs of the United Nations (2016).

5. An analysis of the literature on the popularisation of Bollywood cinema was made in selected case studies.

Results

In geographical research of innovation diffusion, emphasis should be put on the function of the distance of the subjects spreading the innovation. Thus, the key dependent was the distance from Mumbai to the largest urban centre of the countries in which at least one premiere of a Bollywood movie took place. The classification criterion was an equal number of countries in each class - all the countries were divided into six groups, four of which included 13 countries, and two included 12 countries, and these were listed in order of increasing distance (Table. 2).

In the 1970s Bollywood movies were shown in the cinemas of 10 countries outside India. One belonged to class I, situated the nearest to the source of the innovation. From 1970 to 1979 showings were extended to three countries of class III, one of class IV, two of class V, and three of class VI. In the next decade there were 15 new countries, two of which were of class I, three II, one - III, three - IV, five - V, and one of class VI. In the 1990s the number of innovation supporters rose by 11 countries: one of class II, two - III, three - IV, two - V, and three of class VI. The decade from 2000 to 2010 was characterised by a rise in the production and export of Bollywood movies, and these appeared for the first time in 10 countries from class I, $9-\mathrm{II}, 7-\mathrm{III}, 6-\mathrm{IV}$, $4-\mathrm{V}$, and 6 of class VI.

The advancement of Bollywood cinema's spatial diffusion was measured by the number of movies distributed in the study period (Table. 1). For better clarity, the number of distributed movies throughout the whole period was averaged for each class (Table. 3). In the study period, in 13 countries of class I there were 20 movies distributed on average (max. 192 in Kuwait). In the countries of class II the average number of movies was 7 (max. 31 in Singapore). In the next group the average number of movies was 4 (max. 11 in Poland). In class IV the average was 6 and the leading country was Germany (24). Class V (average 53) includes Great Britain, where the biggest number of Bollywood movies of all the countries was distributed (439). In the countries of class $\mathrm{VI}$ the average number of movies shown was 25 (max. USA - 186)

Based on the collected information the conclusion can be drawn that the physical distance between Mumbai and the reception countries did not have an impact on either the timing of the premiere of Bollywood movies in these countries, or on the number of premieres. Thereby, in case of the spatial diffusion of Bollywood cinema, the assumptions of T. Hägerstrand's theory regarding the significance of the relation that the course of the process has with the distance from source sites to reception sites were not confirmed. The aforementioned analysis allows us to confirm the first and second hypotheses proposed above. However, it is worth mentioning that for some groups of countries the neighbourhood effect can be observed. It is manifested by an interest in Bollywood productions in countries close to a country where they have already gained popularity. This applies primarily to European countries in the $1^{\text {st }}$ decade of the $21^{\text {st }}$ century, when the popularity of Bollywood productions spread across the borders of Great Britain to other countries, such as: Ireland, the Netherlands, France, Germany and Poland.

The popularity gained by Bollywood cinema at the turn of the $21^{\text {st }}$ century might have resulted from the Indian diaspora supporting their national cinema. This dependency is particularly evident from the mid-90s, when a tendency to screen the life of Indian emigrants emerged, accompanied by the image of Indian people living abroad becoming more positive. These steps contributed to the rise in audience numbers of spectators in cinemas among the Indian diaspora.

The countries where Bollywood movies were distributed were ranked by size of Indian diaspora. They were divided into groups of the same size (four classes of 13 countries and two of 12 countries; Table. 4$)$.

In the period 1970-1979 Bollywood movies were distributed in 10 countries. In the next decade cinema repertoires were extended to include Bollywood productions in 13 countries, in 11 countries in the 1990s, and in 42 after 2000.

The advancement of the spatial diffusion in the countries ranked by size of Indian diaspora was shown using the average number of productions distributed in the countries of each class (Table 5). In class I countries, the average number of premiere screenings was 79 (439 in Great Britain, 192 in Kuwait, 186 in the United States). In class II countries, with a considerable size of Indian diaspora, the average was 12 (max. 42 in Australia). In class III, which has an average of 7 , Germany stands out with 24 productions. In class IV the average number of movies screened in cinemas was 4 (the most being 13, in Japan). In the countries belonging to the two lowest classes there were few movies screened - in class $\mathrm{V}$ their average number was 10 , due to the very large contribution of Ireland (99), and the considerable 
Table. 1. Distance from Mumbai, size of diaspora and number of Bollywood movies distributed in the referred countries.

\begin{tabular}{|c|c|c|c|c|c|c|}
\hline No. & Country & $\begin{array}{l}\text { Distance of largest urban } \\
\text { centre from Mumbai (km) }\end{array}$ & Class & $\begin{array}{l}\text { Size of the Indian } \\
\text { diaspora }\end{array}$ & Class & $\begin{array}{c}\text { Number of Bollywood } \\
\text { movies distributed } \\
\text { 1970-2010 }\end{array}$ \\
\hline 1. & Argentina & 14,950 & $\mathrm{VI}$ & 1,600 & $\mathrm{~V}$ & 1 \\
\hline 2. & Armenia & 3,585 & 1 & 200 & $\mathrm{VI}$ & 1 \\
\hline 3. & Australia & 10,170 & $\mathrm{VI}$ & 190,000 & II & 48 \\
\hline 4. & Austria & 5,980 & IV & 12,000 & III & 8 \\
\hline 5. & Bahrain & 2,420 & $\mathrm{I}$ & 130,000 & II & 7 \\
\hline 6. & Barbados & 13,720 & $\mathrm{VI}$ & 2,200 & IV & 1 \\
\hline 7. & Belarus & 5,460 & III & 100 & $\mathrm{VI}$ & 1 \\
\hline 8. & Belgium & 6,880 & $\mathrm{~V}$ & 7,000 & IV & 11 \\
\hline 9. & Brazil & 13,790 & $\mathrm{VI}$ & 1,900 & IV & 5 \\
\hline 10. & Canada & 12,500 & $\mathrm{VI}$ & 851,000 & 1 & 55 \\
\hline 11. & Chile & 16,090 & VI & 650 & $\mathrm{~V}$ & 1 \\
\hline 12. & China & 4,750 & II & 300 & VI & 1 \\
\hline 13. & Columbia & 15,550 & $\mathrm{VI}$ & 100 & $\mathrm{VI}$ & 1 \\
\hline 14. & Czech Republic & 6,165 & IV & 400 & $\mathrm{~V}$ & 3 \\
\hline 15. & Denmark & 6,430 & IV & 2,200 & IV & 1 \\
\hline 16. & Egypt & 4,360 & II & 1,400 & $\mathrm{~V}$ & 4 \\
\hline 18. & Estonia & 5,900 & III & 100 & $\mathrm{VI}$ & 2 \\
\hline 19. & Fiji & 12,250 & $\mathrm{VI}$ & 337,000 & $\mathrm{I}$ & 5 \\
\hline 20. & Finland & 5,930 & IV & 1,200 & $\mathrm{~V}$ & 2 \\
\hline 21. & France & 7,020 & $\mathrm{~V}$ & 65,000 & II & 22 \\
\hline 22. & Germany & 6,690 & IV & 35,000 & III & 24 \\
\hline 23. & Ghana & 8,040 & $\mathrm{~V}$ & 3,800 & IV & 1 \\
\hline 24. & Great Britain & 7,200 & $\mathrm{~V}$ & $1,200,000$ & I & 439 \\
\hline 25. & Greece & 5,180 & III & 7,000 & IV & 4 \\
\hline 26. & Hong Kong & 4,300 & II & 50,500 & II & 4 \\
\hline 27. & Hungary & 5,770 & III & 1,000 & $\mathrm{~V}$ & 3 \\
\hline 28. & Indonesia & 4,660 & II & 55,000 & II & 8 \\
\hline 29. & Iran & 2,800 & I & 800 & $\mathrm{~V}$ & 1 \\
\hline 30. & Ireland & 7,610 & $\mathrm{~V}$ & 1,600 & $\mathrm{~V}$ & 99 \\
\hline 31. & Island & 8,340 & $\mathrm{~V}$ & 100 & $\mathrm{VI}$ & 1 \\
\hline 32. & Israel & 4,060 & II & 45,300 & III & 6 \\
\hline 33. & Italy & 6,180 & IV & 71,500 & II & 8 \\
\hline 34. & Japan & 6,732 & $\mathrm{~V}$ & 10,000 & IV & 13 \\
\hline 35. & Kazakhstan & 3,570 & $\mathrm{I}$ & 1,100 & $\mathrm{~V}$ & 3 \\
\hline 36. & Kenya & 4,570 & II & 102,500 & II & 3 \\
\hline 37. & Kuwait & 2,810 & I & 295,000 & I & 192 \\
\hline 38. & Kyrgyzstan & 2,650 & 1 & 100 & $\mathrm{VI}$ & 1 \\
\hline 39. & Latvia & 5,800 & III & 600 & $\mathrm{~V}$ & 1 \\
\hline 40. & Lebanon & 4,040 & II & 11,000 & III & 2 \\
\hline 41. & Malaysia & 3,600 & II & $1,665,000$ & $\mathrm{I}$ & 15 \\
\hline 42. & Mauritius & 4,680 & II & 716,000 & I & 4 \\
\hline 43. & Mexico & 15,670 & $\mathrm{VI}$ & 400 & $\mathrm{~V}$ & \\
\hline 44. & Morocco & 8,000 & $\mathrm{~V}$ & 350 & $\mathrm{VI}$ & 3 \\
\hline 45. & Nepal & 1,590 & 1 & 540,000 & I & 2 \\
\hline 46. & New Zealand & 12,380 & $\mathrm{VI}$ & 55,000 & II & 12 \\
\hline 47. & Nigeria & 7,630 & $\mathrm{~V}$ & 25,000 & III & 1 \\
\hline 48. & Norway & 6,650 & IV & 5,600 & IV & 4 \\
\hline 49. & Oman & 1,580 & 1 & 312,000 & 1 & 3 \\
\hline 50. & Pakistan & 1,630 & I & $2,160,000$ & $\mathrm{I}$ & 27 \\
\hline 51. & Panama & 15,820 & $\mathrm{VI}$ & 2,200 & IV & 1 \\
\hline 52. & Peru & 16,720 & $\mathrm{VI}$ & 100 & $\mathrm{VI}$ & 3 \\
\hline 53. & Philippines & 5,135 & III & 38,000 & III & 5 \\
\hline
\end{tabular}


MISCELLANEA GEOGRAPHICA - REGIONAL STUDIES ON DEVELOPMENT

Vol. 23 • No. $1 \cdot 2019 \cdot$ pp. 33-38 •ISSN: 2084-6118 • DOI: 10.2478/mgrsd-2018-0030

Table. 1. Distance from Mumbai, size of diaspora and number of Bollywood movies distributed in the referred countries.

\begin{tabular}{|c|c|c|c|c|c|c|}
\hline No. & Country & $\begin{array}{l}\text { Distance of largest urban } \\
\text { centre from Mumbai (km) }\end{array}$ & Class & $\begin{array}{l}\text { Size of the Indian } \\
\text { diaspora }\end{array}$ & Class & $\begin{array}{c}\text { Number of Bollywood } \\
\text { movies distributed } \\
1970-2010\end{array}$ \\
\hline 54. & Poland & 5,790 & III & 800 & $\mathrm{~V}$ & 11 \\
\hline 55. & Portugal & 8,030 & $\mathrm{~V}$ & 70,000 & II & 6 \\
\hline 56. & Qatar & 2,300 & $\mathrm{I}$ & 131,000 & II & 2 \\
\hline 57. & $\begin{array}{c}\text { Russia/Soviet } \\
\text { Union }\end{array}$ & 5,030 & III & 16,000 & III & 8 \\
\hline 58. & Singapore & 3,900 & II & 50,000 & II & 31 \\
\hline 59. & Slovakia & 5,930 & IV & 100 & $\mathrm{VI}$ & 1 \\
\hline 60. & Slovenia & 6,080 & IV & 100 & $\mathrm{VI}$ & 2 \\
\hline 61. & South Africa & 8,250 & $\mathrm{~V}$ & $1,000,000$ & 1 & 21 \\
\hline 62. & South Korea & 5,600 & III & 2,700 & IV & 7 \\
\hline 63. & Spain & 7,540 & $\mathrm{~V}$ & 29,000 & III & 8 \\
\hline 64. & Sri Lanka & 1,550 & 1 & 30,000 & III & 1 \\
\hline 65. & Sudan & 4,300 & II & 1,500 & $\mathrm{~V}$ & 1 \\
\hline 66. & Sweden & 6,240 & IV & 11,000 & III & 7 \\
\hline 67. & Switzerland & 6,550 & IV & 13,500 & III & 13 \\
\hline 68. & Syria & 3,975 & II & 1,800 & IV & 1 \\
\hline 69. & Taiwan & 5,040 & III & 1,800 & IV & 4 \\
\hline 70. & Tanzania & 4,950 & III & 90,000 & II & 3 \\
\hline 71. & Thailand & 3,000 & $\mathrm{I}$ & 85,000 & II & 3 \\
\hline 72. & $\begin{array}{c}\text { The } \\
\text { Netherlands }\end{array}$ & 6,860 & V & 217,000 & 1 & 68 \\
\hline 73. & Tunisia & 6,360 & IV & 100 & $\mathrm{VI}$ & 1 \\
\hline 74. & Turkey & 4,815 & III & 300 & $\mathrm{VI}$ & 6 \\
\hline 75. & $\begin{array}{c}\text { United Arab } \\
\text { Emirates }\end{array}$ & 2,000 & 1 & 950,000 & I & 16 \\
\hline 76. & USA & 12,550 & $\mathrm{VI}$ & $1,679,000$ & 1 & 186 \\
\hline 77. & Zimbabwe & 6,150 & IV & 16,700 & III & 1 \\
\hline
\end{tabular}

Source: author's own work

Table. 2. Number of countries with their $1^{\text {st }}$ Bollywood premiere in 1970-2010

\begin{tabular}{|c|c|c|c|c|c|}
\hline Class & Class range $\mathbf{( k m )}$ & $\mathbf{1 9 7 0 - 7 9}$ & $\mathbf{1 9 8 0 - 8 9}$ & $\mathbf{1 9 9 0 - 9 9}$ & $\mathbf{2 0 0 0 - 1 0}$ \\
\hline I & below 3,600 & 1 & 2 & 0 & 10 \\
\hline II & $3,601-4,800$ & 0 & 3 & 1 & 9 \\
\hline III & $4,801-5,900$ & 3 & 3 & 3 & 7 \\
\hline IV & $5,901-6,700$ & 1 & 5 & 2 & 6 \\
\hline V & $6,701-10,000$ & 2 & 1 & 3 & 6 \\
\hline $\mathrm{VI}$ & over 10,000 & 3 & 1 & 2 & 6 \\
\hline
\end{tabular}

Author's own work

Table. 3. Number of Bollywood movies in countries classified by distance from Mumbai

\begin{tabular}{|c|c|c|c|c|c|c|}
\hline Class & I & II & III & IV & V & VI \\
\hline Movies - total & 259 & 80 & 57 & 73 & 693 & 324 \\
\hline Movies - average & 20 & 7 & 4 & 6 & 53 & 25 \\
\hline
\end{tabular}

Source: author's own work 
Table. 4. Number of countries with 1st Bollywood premiere in 1970-2010

\begin{tabular}{|c|c|c|c|c|c|}
\hline Class & Class range (pop.) & 1970-1979 & 1980-1989 & 1990-1999 & 2000-2010 \\
\hline I & over 200,000 & 3 & 1 & 2 & 7 \\
\hline II & $50,000-200,000$ & 1 & 4 & 2 & 5 \\
\hline III & $11,000-49,999$ & 2 & 3 & 1 & 6 \\
\hline IV & $1,800-10,999$ & 0 & 2 & 2 & 7 \\
\hline V & $400-1,799$ & 2 & 1 & 1 & 9 \\
\hline VI & below 400 & 2 & 3 & 2 \\
\hline
\end{tabular}

Source: author's own work

Table. 5. Number of Bollywood movies in countries classified by size of Indian diaspora

\begin{tabular}{|c|c|c|c|c|c|c|}
\hline Class & I & II & III & IV & V & VI \\
\hline Movies - total & 1,033 & 157 & 84 & 53 & 135 & 24 \\
\hline Movies - average & 79 & 12 & 7 & 4 & 10 & 2 \\
\hline
\end{tabular}

Source: author's own work

contribution of Poland (11). Among the countries from class $\mathrm{VI}$, where the average was 2 , the only countries that achieved betterthan-average results were Turkey (6) and Peru (3).

The hypothesis regarding how the point in time that Bollywood movies were introduced to receptive countries' cinemas relates to the size of their Indian diaspora was not confirmed. Bollywood cinema appeared in reception countries in different periods and it is hard to associate it with the size of diaspora. But such a dependency can be seen in how the number of Bollywood movies distributed in the reception countries related to the size of the Indian diaspora. The average number of distributed movies decreases in direct proportion to the number of people of Indian origin living in the groups of countries. These dependencies are not rectilinear - a distinct aberration can be observed in the group of countries that contains Ireland, where Bollywood cinema gained popularity despite there being only a small Indian diaspora. The reasons for this can be detected in the small distance from Great Britain, where the cinema was popularised due to its strong Indian diaspora. It is possible that this was due to the neighbourhood effect, which is typical for spatial diffusion. In the case of such a heterogeneous innovation as a nearly six-thousand-strong sample of movies, it is hard to expect unambiguous dependencies, thus the collected data lead to the confirmation of the fourth hypothesis.

The analysis of case studies in various countries makes it possible to indicate additional circumstances that had an impact on the course of the spatial diffusion. Other factors stimulating the spread of Indian cinema in various countries include topdown measures by authorities. In Pakistan these took on various forms, depending on the geopolitical situation. In times of intense conflict between India and Pakistan, Bollywood cinema presented Pakistanis as cowards and hostile antiheroes (Ud Din \& Langah 2012), which led to Bollywood movies being censored or banned from Pakistani cinemas. Each time the contacts between the countries became friendlier, this was reflected in cinema - large-scale movies were made that called for peace between the countries (Kołodyński 2009). Nepal and Bangladesh had a long history of Indian movie censorship, too. These actions were caused by the countries being portrayed negatively in these movies, the desire to protect national cinematography markets, or political misunderstandings and tensions (Ud Din \& Langah 2012; Khan 2012). South Africa's ban on distributing Indian cinema in response to India's objection to apartheid lasted for over half a century. Authorities in Australia, which was a lead shooting location for Bollywood movies, used them to present the country as tolerant and open towards foreign tourists and students (Hassam 2012). The Soviet Union actively supported the popularisation of Indian cinema as a result of long-lasting relations with India, while at the same time promoting traditional models that were alternative to those propagated by American or European cinema (Igorevna Doroshenko 2012; YanderSteene 2012). According to YanderSteene (2012), in Senegal and Nigeria the peoples using the Wolof, Fulani, or Hausa language watched movies produced in Hindi due to their short and relatively infrequent dialogue and an alleged similarity in the sounds of these languages.

\section{Summary}

It has been proven that neither the small distance of reception countries from Mumbai, nor the presence of a large Indian diaspora had an impact on the time of the premiere of Bollywood movies in the cinemas of these countries. The analysis did not show any dependence between the distance of the reception countries from Mumbai and how spatially diffused Bollywood cinema was. A relation was observed between the size of the Indian diaspora in the reception countries and the number of distributed Bollywood movies. Strong associations of cultural products, especially of Indian cinema and the shaping of national identity among the Indian diaspora, have already been proven by N. Kumar \& J.-B. E. M. Steenkamp (2013), S. Rao (2010) and R. Bandyopadhyay (2008). Probably because of the neighbourhood effect, in Ireland, where the Indian diaspora is little, cinemas screened nearly 100 movies, and the first had its premiere there in only 2002. This effect can also be detected in Poland, Germany and the countries of the Arabian Peninsula. The hypotheses regarding the dependence of the start time and course of the spatial diffusion of Bollywood cinema, and the distance and diaspora size were made probable, except for the third hypothesis.

Analysis of the case studies and classification of the countries support the conclusion that the course of Bollywood cinema 
diffusion was significantly influenced by additional circumstances present in the selected countries. They took the form of barriers that inhibited or stopped the diffusion of Bollywood cinema in places with circumstances that facilitated the popularisation of this kind of cinema (spatial and cultural proximity). These results may have been influenced by the nature of the tested subject of the innovation - a very large and diverse group of movies. The method by which movies are accepted for cinema distribution - a direct decision by film distributors and, in some cases, the authorities - also played a decisive role. In these circumstances the expected implications were not rectilinear, although the results were satisfactory and reliable.

Finally, it is worth mentioning a few insights upon obtaining the research results. Firstly, data only on the size of the Indian diaspora in certain countries may seem incomplete without reference to the broader cultural, social and political context. Such a conclusion was made by, among others, R. Bandyopadhyay (2008), in analysing the national identity of the Indian diaspora. Including these data could create a more complete picture of the diaspora's impact on the dissemination of its native culture, but it would be very difficult to collect such detailed, reliable data for the more than 70 countries analysed. The adopted timeframe allowed for different trends to be seen in the global dissemination of popular Hindi cinema, but, as a result, it masked the role of ephemeral but significant trends, such as the growing popularity of Hindi cinema in Europe at the beginning of the $21^{\text {st }}$ century. Subsequently, the deliberate inclusion of only cinematic distribution made it possible to achieve the goals of the paper. However, there could be a number of factors that influenced the cinematic distribution of films before they were digitised, which could have contributed to other barriers that were omitted in this paper. Nevertheless, the above considerations are proof that the problem analysed in the above paper was complex and worth developing.

\section{References}

Bandyopadhyay, R 2008, 'Nostalgia, Identity and Tourism: Bollywood in the Indian Diaspora', Journal of Tourism and Cultural Change, vol. 6, no. 2, pp. $79-100$

Department of Economic and Social Affairs, 2016, International Migration Report 2015 [highlights]. Available from: <http:// www.un.org/en/development/desa/population/migration/ publications/migrationreport/docs/MigrationReport2015 Highlights.pdf>. [4 March 2017].

DistanceFromTo: Distance between cities and places, n.d. Available from: <http://www.distancefromto.net/>. [20 February 2017].

Hassam, A 2012, 'Bollywood Internet Forums and Australian Cultural Diplomacy' in The Magic of Bollywood: At Home And Abroad, ed AG Roy, SAGE Publications India, New Delhi, pp. 254-276.

Hägerstrand, T 1967, Innovation diffusion as a spatial process, transl. Allan Pred, The University of Chicago Press, Chicago.

High Level Committee On Indian Diaspora, 2001, Executive Summary in: Report of the High Level Committee on the Indian Diaspora, pp. xi-xl. Available from: <https://www.mea. gov.in/images/pdf/1-executive-summary.pdf>. [17 October 2018].

High Level Committee On Indian Diaspora, 2016, Population of Overseas Indians. Available from: <http://mea.gov.in/ images/attach/NRIs-and-PIOs_1.pdf>. [22 April 2017].

Igorevna Doroshenko, I 2012, 'Indian Films in the USSR and Russia: Past, Present, and Future' in The Magic of Bollywood: At Home And Abroad, ed AG Roy, SAGE Publications India, New Delhi, pp. 161-177.

IMDb, n.d. Available from: <www.imdb.com>. [25 April 2017].

Kaur, R \& Sinha, AJ 2005, Bollyworld: Popular Indian Cinema Through a Transnational Lens, Sage Publications, Los Angeles.
Khan, S 2012, 'Soft Power and Pakistani Viewers' in The Magic of Bollywood: At Home And Abroad, ed AG Roy, SAGE Publications India, New Delhi, pp. 125-143.

Kołodyński, A 2009, ,Zwycięstwo arkadii'['The victory of arcadia'] in Nie tylko Bollywood ['Not only Bollywood'], eds G Stachówna \& P Piekarski, Korporacjaha!art, Kraków, pp. 371-388.

Kumar, N \& Steenkamp, J-BEM 2013, 'Diaspora marketing', Harvard Business Review, vol. 91, no. 10, pp. 127-131.

Mehta, RB \& Pandharipande, R (eds) 2010, Bollywood and Globalization. Indian Popular Cinema, Nation and Diaspora, Anthem Press, London, pp. 1-14.

Rao, S 2010 'I Need an Indian Touch": Glocalization and Bollywood Films', Journal of International and Intercultural Communication, vol. 3, no. 1, pp. 1-19.

Roy, AG (ed) 2012, The Magic of Bollywood: At Home And Abroad, SAGE Publications India, New Delhi

Roy, AG \&Huat CB (eds) 2012, Travels of Bollywood Cinema. From Bombay to $L A$, Oxford University Press, New Delhi

Stachówna, G \&Piekarski, P (eds) 2009, Nie tylko Bollywood [Not only Bollywood], Korporacjaha!art, Kraków

Ud Din, K \& Langah, NT 2012, 'Dada Negativity and Pakistani Characters in Bollywood Films' in The Magic of Bollywood: At Home And Abroad, ed AG Roy, SAGE Publications India, New Delhi, pp. 107-124.

Yander Steene, G 2012, 'Bollywood Films and African Audiences' in Travels of Bollywood Cinema. From Bombay to LA, eds AG Roy \& CB Huat, Oxford University Press, New Delhi, pp. $302-320$ 